\title{
The Climate of the McMurdo, Antarctica, Region as Represented by One Year of Forecasts from the Antarctic Mesoscale Prediction System*
}

\author{
Andrew J. Monaghan and David H. Bromwich \\ Polar Meteorology Group, Byrd Polar Research Center, and Atmospheric Sciences Program, Department of Geography, The Ohio \\ State University, Columbus, Ohio \\ Jordan G. Powers and Kevin W. Manning \\ Mesocale and Microscale Meteorology Division, National Center for Atmospheric Research, Boulder, Colorado
}

(Manuscript received 3 May 2004, in final form 24 September 2004)

\begin{abstract}
In response to the need for improved weather prediction capabilities in support of the U.S. Antarctic Program's Antarctic field operations, the Antarctic Mesoscale Prediction System (AMPS) was implemented in October 2000. AMPS employs a limited-area model, the Polar fifth-generation Pennsylvania State University-National Center for Atmospheric Research (PSU-NCAR) Mesoscale Model (MM5), optimized for use over ice sheets. Twice-daily forecasts from the 3.3-km resolution domain of AMPS are joined together to study the climate of the McMurdo region from June 2002 to May 2003. Annual and seasonal distributions of wind direction and speed, 2-m temperature, mean sea level pressure, precipitation, and cloud fraction are presented. This is the first time a model adapted for polar use and with relatively high resolution is used to study the climate of the rugged McMurdo region, allowing several important climatological features to be investigated with unprecedented detail.

Orographic effects exert an important influence on the near-surface winds. Time-mean vortices occur in the lee of Ross Island, perhaps a factor in the high incidence of mesoscale cyclogenesis noted in this area. The near-surface temperature gradient is oriented northwest to southeast with the warmest temperatures in the northwest near McMurdo and the gradient being steepest in winter. The first-ever detailed precipitation maps of the region are presented. Orographic precipitation maxima occur on the southerly slopes of Ross Island and in the mountains to the southwest. The source of the moisture is primarily from the large synoptic systems passing to the northeast and east of Ross Island. A precipitation-shadow effect appears to be an important influence on the low precipitation amounts observed in the McMurdo Dry Valleys. Total cloud fraction primarily depends on the amount of open water in the Ross Sea; the cloudiest region is to the northeast of Ross Island in the vicinity of the Ross Sea polynya.
\end{abstract}

\section{Introduction}

McMurdo Station $\left(77.85^{\circ} \mathrm{S}, 166.67^{\circ} \mathrm{E}\right.$, Fig. 1a) is the base of the U.S. Antarctic Program operations in Antarctica. The history of the site extends back more than a century. Its proximity to a recurring polynya (an area of water or thin ice in pack ice or fast ice) (Armstrong et al. 1973), in addition to being situated in the Ross Sea embayment, made this one of the farthest points southward early explorers could reach by ship before embarking on overland attempts to reach the South Pole (e.g., Scott 1907). The United States has continuously

* Byrd Polar Research Center Contribution Number 1314.

Corresponding author address: Andrew J. Monaghan, Polar Meteorology Group, Byrd Polar Research Center, The Ohio State University, 1090 Carmack Rd., Columbus, OH 43210.

E-mail: monaghan@polarmet1.mps.ohio-state.edu occupied McMurdo as a station for scientific endeavors since 1956.

Throughout its history, explorers and researchers have noted that the atmospheric dynamics of the region are complex (National Antarctic Expedition, 19011904, 1908; Simpson 1919). This is in part due to the striking terrain; 3500-m-high peaks dot the coastline of Victoria Land to the immediate west of the station, and McMurdo itself is located on Ross Island at the base of a 3794-m active volcano, Mt. Erebus (Fig. 1b). In addition, the station is located at the confluence of three dissimilar air masses: very cold, dry air from the high continental plateau of East Antarctica to the west; cold and somewhat moister air from the low-lying Ross Ice Shelf to the south; and relatively warm, moist maritime air from the Ross Sea to the north. It is not surprising then that these ingredients often combine to shape abrupt and severe weather that can cripple McMurdo for days. Meteorologists have documented intense katabatic winds flowing from the nearby glacial valleys 
a) AMPS domains

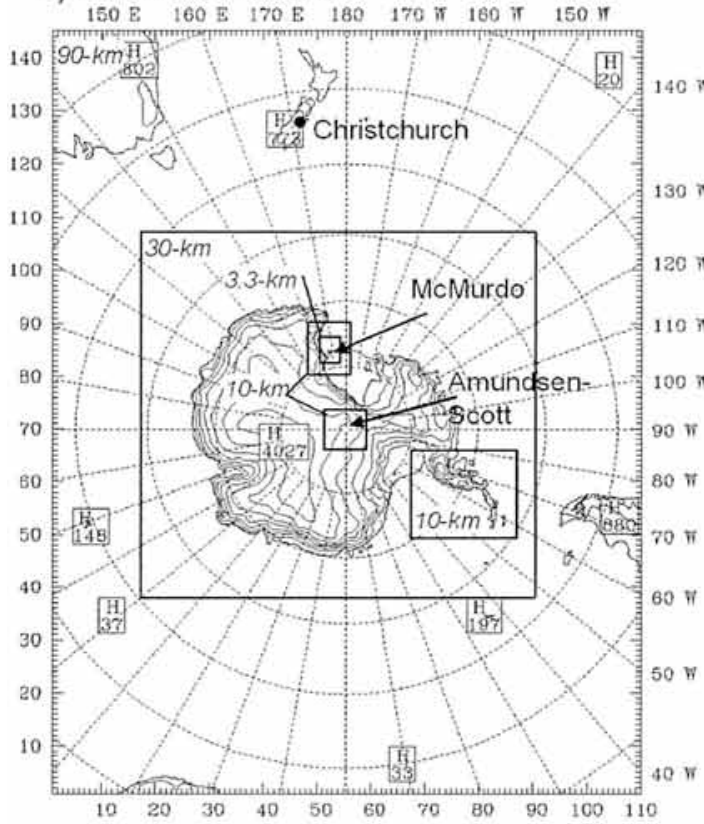

b) RAMP DEM ("observed") topography
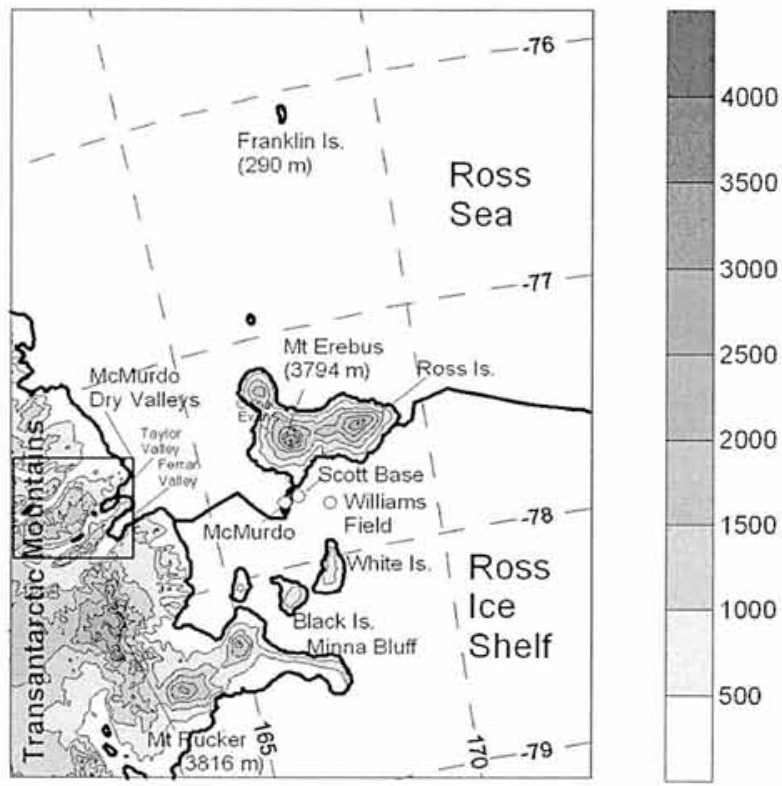

c) AMPS 30-km model topography

\section{d) AMPS 3.3-km model topography}
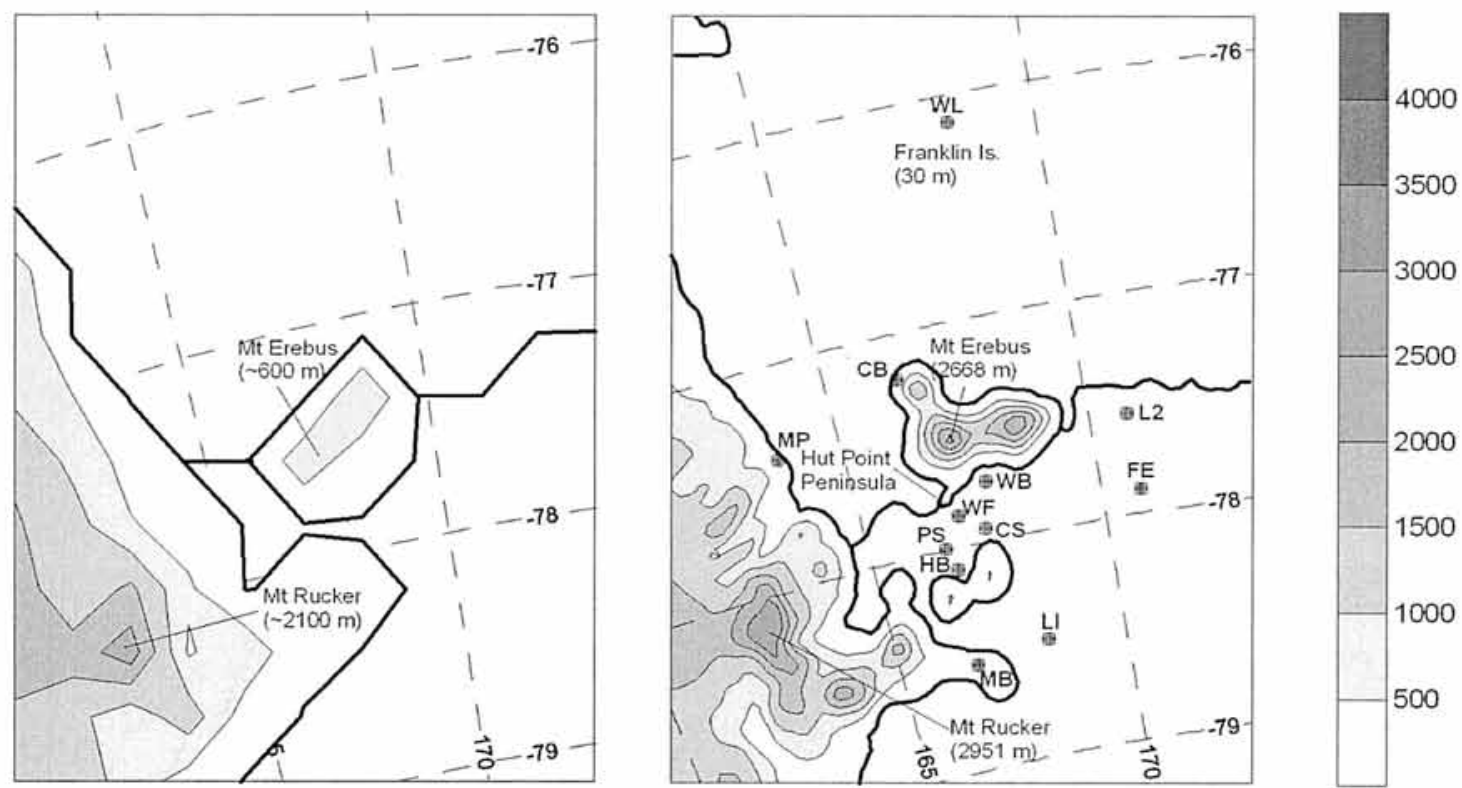

FIG. 1. (a) The six AMPS domains. (b) The USGS GTOPO30 ("observed") topography (m ASL) in the McMurdo region. (c) The AMPS 30-km domain topography (m ASL). (d) The AMPS 3.3-km domain topography (m ASL). The locations of the AWSs used to evaluate model performance are indicated by dots in (d). The AWS abbreviations are: WL: Whitlock, CB: Cape Bird, MP: Marble Point, WB: Windless Bight, WF: Williams Field, CS: Cape Spencer, PS: Pegasus South, HB: Herbie Alley, LI: Linda, MB: Minna Bluff, L2: Lauri II, and FE: Ferrell.

(e.g., Bromwich 1989, 1991), cyclonically forced barrier winds propagating northward along the Transantarctic Mountains (e.g., O'Connor et al. 1994), and one of the most active regions of mesoscale cyclogenesis on earth adjacent to Ross Island (Bromwich 1991; Carrasco and
Bromwich 1994, 1996; Gallée 1996; Carrasco et al. 2003). Blowing snow and fog frequently suspend aircraft operations on the local runways (A. Cayette, Aviation Technical Services, 2003, personal communication). 
Due to its relatively long history and large concentration of researchers compared to many other areas of the continent, the greater McMurdo area hosts one of the densest observational networks in Antarctica. About 40 or so automatic weather stations (AWSs) reside within a $50-\mathrm{km}$ radius of McMurdo, and surface and upper-air observations are recorded regularly at the base. Thus, numerous studies of various aspects of the regional climate have been published to date; a brief review of some of these is presented below.

The winds in the region have perhaps intrigued researchers the most over the years and have lead to a wealth of studies. Simpson (1919) observed that sudden wintertime warming events at Cape Evans were concurrent with the onset of strong winds and surmised that these were due to the erosion of the near-surface inversion. Simpson was also the first to note the deflection of winds around Hut Point Peninsula. Mather and Miller (1967), Sinclair (1982), Slotten and Stearns (1987), Bromwich (1988a), O'Connor and Bromwich (1988), and Seefeldt et al. (2003) examined the spatial distribution of the winds using manned observations, AWSs, satellite imagery, and, most recently, numerical modeling. They noted the strong influence of the orography of Ross Island, especially the deflection of the dominant southerly winds around to the east and west of the island. Savage and Stearns (1985), Stearns and Weidner (1993), Stearns et al. (1993), Holmes and Stearns (1995), Stearns (1997), and Holmes et al. (2000) employed AWSs to construct climatologies of temperature and pressure, in addition to the winds in the region. Savage and Stearns (1985) noted the sharp temperature gradient between McMurdo and the Ross Ice Shelf to the southeast and showed that a quasi-permanent eastward-directed pressure gradient along the Transantarctic Mountains provided evidence for the persistent barrier wind regime. Bull (1966), Sinclair (1982), and Bromwich (1988b) presented some of the first precipitation and snow accumulation estimates for McMurdo; the latter two authors concluded that the annual mean precipitation amount is about $180-190 \mathrm{~mm}$ water equivalent. Thompson and McDonald $(1961,1962)$ and Thompson $(1968,1969)$ examined the climate of New Zealand's Scott Base (Fig. 1b), adjacent to McMurdo, in considerable detail. Thompson and McDonald (1961) demonstrated the important influence of topography on regional climate by observing a difference of several degrees Celsius in mean annual temperature between Scott Base and McMurdo, which are only about $2 \mathrm{~km}$ apart but are separated by the $\sim 300 \mathrm{~m}$ high Hut Point Peninsula.

These studies have greatly enhanced knowledge of the region. However, as most rely on the observational network, it is difficult to spatially extrapolate the results beyond limited radii of influence due to variable topography and complex atmospheric interactions; therefore, large areas still exist for which little or nothing is known of the near-surface climatologies of any atmospheric parameters. In addition, precipitation and cloud cover are only measured year-round at McMurdo; thus, the regional distribution of these variables is poorly understood. By comparing the annual and seasonal wind, temperature, pressure, precipitation, and cloud fraction fields side by side, important aspects of the regional climate can be studied in greater detail than previously possible. Some specific examples include investigating where precipitation shadows occur and why mesoscale cyclones form with high frequency to the north of Ross Island.

Here, a relatively new resource is used to explore the seasonal and annual climate of the McMurdo region with high spatial resolution: an archive of numerical weather model forecasts from the Antarctic Mesoscale Prediction System (AMPS). AMPS is an experimental forecasting system run at the Mesoscale and Microscale Meteorology division of the National Center for Atmospheric Research (NCAR) and dedicated to real-time numerical weather prediction in Antarctica since October 2000 (Powers et al. 2003; more information available online at http://www.mmm.ucar.edu/rt/mm5/amps/). AMPS employs the Polar version of the fifth-generation Pennsylvania State University-National Center for Atmospheric Research (PSU-NCAR) Mesoscale Model (MM5; Grell et al. 1994) optimized for the environment of polar ice sheets by the Polar Meteorology Group of the Byrd Polar Research Center at Ohio State University (Bromwich et al. 2001; Cassano et al. 2001; more information available online at http://polarmet. mps.ohio-state.edu). AMPS is a collaborative effort between NCAR and Ohio State. The role of NCAR is to run AMPS twice daily, provide a Web interface and model products to the international forecasting community, archive the forecasts, and maintain the model code. The role of Ohio State is to continue development of the model physics and to evaluate the system's performance.

AMPS consists of six domains (Fig. 1a): 1) a 90-km resolution domain covering most of the Southern Hemisphere; 2) a 30-km domain over the Antarctic continent; 3) a $10-\mathrm{km}$ domain covering the western Ross Sea; 4) a 3.3-km domain covering the immediate Ross Island region (implemented in December 2001); 5) a $10-\mathrm{km}$ domain encompassing Amundsen-Scott South Pole Station (implemented in November 2001); and 6) a 10-km domain enclosing the Antarctic Peninsula (implemented in September 2003). A general overview of AMPS is provided by Powers et al. (2003), along with a description of two noteworthy international rescue efforts in which AMPS provided invaluable forecast guidance. Since that publication, the system has provided guidance for medical evacuations in September 2003 from South Pole and in April 2004 from McMurdo. Several published studies have shown that Polar MM5 performs with good skill on hourly to seasonal time scales over Antarctica (Bromwich et al. 
2003; Guo et al. 2003; Monaghan et al. 2003; Bromwich et al. 2005). On seasonal time scales the intraseasonal and interseasonal variability in pressure, temperature, wind, and moisture are particularly well resolved (Guo et al. 2003). Bromwich et al. (2005) compare the AMPS 10- and 3.3-km resolution McMurdo forecast domains and find that the $3.3-\mathrm{km}$ domain provides an enhanced depiction of the near-surface winds due to its ability to capture more of the high-frequency energy that is characteristic of the small space scales and short time scales of the region. This is largely due to the more representative topography of the $3.3-\mathrm{km}$ domain, which is evident by comparing the extreme case of the 30- and 3.3-km domains (Figs. 1c and 1d) to the United States Geological Survey global 30-arc-second digital elevation model (GTOPO30; Fig. 1b), which represents the "observed" terrain. For example, the height of Mt. Erebus on Ross Island is $\sim 600 \mathrm{~m}$ on the $30-\mathrm{km}$ grid compared to $2668 \mathrm{~m}$ on the $3.3-\mathrm{km}$ grid and $3794 \mathrm{~m}$ in reality.

The AMPS archive extends back to January 2001; for the more recently implemented $3.3-\mathrm{km}$ domain employed in this study, the archive extends back to midDecember 2001. The climate of one complete annual cycle over the McMurdo region is constructed here. The major advantage of using the archived AMPS 3.3$\mathrm{km}$ forecasts rather than "hindcasting" the climate with a limited-area model forced by a large-scale analysis (as is often done) is that it would be computationally expensive to hindcast for a grid of this resolution, considering the short time step and nesting required. The period chosen is June 2002-May 2003 because few changes were made to the AMPS configuration over these 12 months and because it is a fairly representative year (this is argued in more detail in section 3 ). While the seasonal variability and the annual climate can be constructed here in the highest resolution and most complete manner to date, it is not yet possible to assess interannual variability.

The layout of this paper is as follows: in section 2, the Polar MM5 and the AMPS configuration are covered in more detail; in section 3, the long-term observed, 200203 observed, and 2002-03 modeled fields are compared; in section 4, the climatological fields are presented; and in section 5 , conclusions are drawn.

\section{Polar MM5 and AMPS}

A full description of the standard MM5 modeling system is given by Grell et al. (1994). Bromwich et al. (2001) and Cassano et al. (2001) give a detailed description of the important changes to MM5 to optimize the model for use over ice sheets as the Polar MM5. These include a modified parameterization for the prediction of ice cloud fraction, improved cloud-radiation interactions, an optimized stable boundary layer treatment, improved calculation of heat transfer through snow and ice surfaces, and the addition of a fractional sea ice surface type. Bromwich et al. (2005) describe the model as configured for AMPS. A brief summary is given here.

The AMPS Polar MM5 consists of the six polar stereographic domains at the horizontal resolutions described in section 1 and shown in Fig. 1. Prior to 20 May 2003, there were 29 vertical half-sigma levels, with 11 levels in the lowest $1000 \mathrm{~m}$ to capture the complex interactions in the planetary boundary layer. After this, the model top was raised from 100 to $50 \mathrm{hPa}$, and two half-sigma levels were added. This has minimal impact on the results presented here, as our period of interest ends at about the same time this change was made. The lowest half-sigma level is about $13 \mathrm{~m}$ above the surface. The model topography for the $3.3-\mathrm{km}$ domain is interpolated from a modern $5-\mathrm{km}$ resolution digital elevation model for Antarctica (Liu et al. 1999), the RAMP DEM. The regions spanned by the Ronne/Filchner Ice Shelf and Ross Ice Shelf are specified as permanent ice. Due to the fine horizontal resolution, the moist processes for the 3.3-km domain employed in this study are fully explicit. This configuration has been in effect since December 2002. Prior to that, moist processes included the Grell et al. (1994) cumulus parameterization. It is likely that the change in December 2002 had minimal impact on total precipitation for the period evaluated, as there is very little subgrid-scale (convective) precipitation in the six relatively cold months prior to December 2002.

The AMPS Polar MM5 is initialized twice daily at 0000 and 1200 UTC. The 90- and 30-km forecasts extend out to $72 \mathrm{~h}$ (120 h as of August 2004), and the 10and $3.3-\mathrm{km}$ forecasts extend out to $36 \mathrm{~h}$. The initial and boundary conditions are derived from the National Centers for Environmental Prediction (NCEP) Global Forecasting System model and supplemented by observations including reports from manned surface stations, AWSs, and upper-air stations via the objective analysis scheme of Nuss and Titley (1994). Satellite-derived cloud track winds are also assimilated in the $90-\mathrm{km}$ grid. The system ingests sea ice data daily from the National Snow and Ice Data Center for its fractional sea ice depiction. The data are derived from the Special Sensor Microwave Imager (SSM/I) aboard the polar-orbiting satellites of the Defense Meteorological Satellite Program (DMSP). Figure 2 compares the AMPS sea ice fraction to a DMSP visible satellite image on 20 December 2001, processed using the Terascan software. The sea ice is reasonably captured in the AMPS fields. However, the large iceberg that extends northward from Ross Island is not depicted. This $\sim 11000 \mathrm{~km}^{2}$ iceberg, named B-15A, broke off from the Ross Ice Shelf in March 2000 and became grounded in the position indicated. As of this writing it is still grounded, although it broke into two pieces in October 2003. Because open water or sea ice, rather than the iceberg, are 


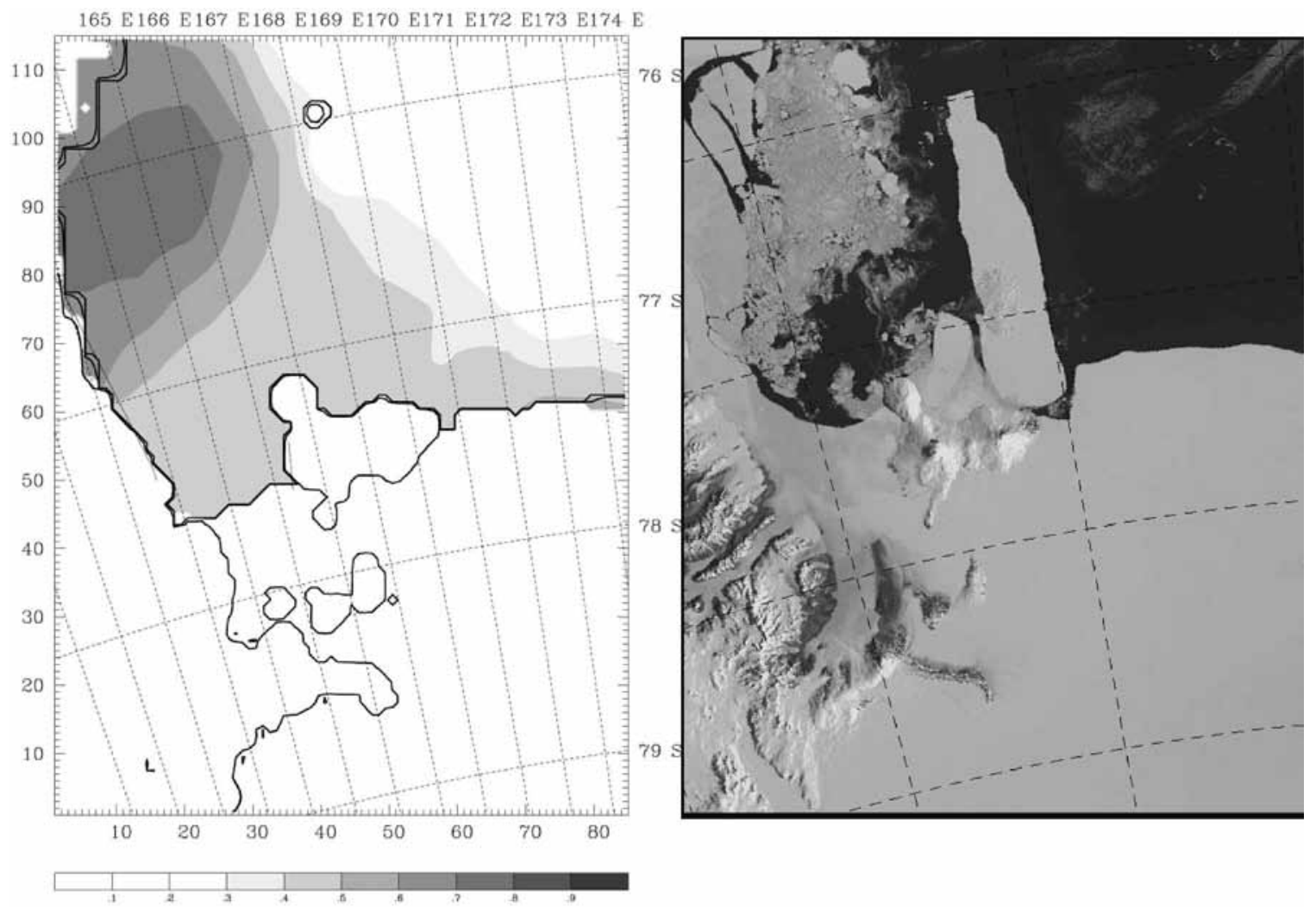

FIG. 2. (a) SSM/I-derived sea ice fraction in the AMPS 1200 UTC forecast on 20 Dec 2001 and (b) the DMSP visible satellite image from 1800 UTC 20 Dec 2001.

depicted in the model fields, it is speculated that the model fields in the Ross Island region may be slightly moister and warmer than they would be otherwise. However, the winds in this region are primarily from the south (e.g., Seefeldt et al. 2003), thus the impact on Ross Island and regions southward is likely minimal.

In this study, seasonal and annual mean fields are constructed by joining hundreds of AMPS $3.3-\mathrm{km}$ domain 24-, 27-, 30-, and 33-h forecasts. Therefore, each pair of 0000 and 1200 UTC model initializations provide data at 0000, 0300, 0600, 0900, 1200, 1500, 1800, and 2100 UTC on the next day. The later forecast hours are chosen to allow the model fields to spin up. This is especially important for clouds and precipitation, which are not present in the initial conditions. Choosing these later forecast hours, rather than using output from earlier in the forecasts when the model skill is expected to be better, has little impact on the results. This is shown in Table 1, which presents the bias, root-mean-square error (rmse), and correlation coefficient between the model and observations for all 6-hourly AMPS 3.3-km forecasts between June 2002 and May 2003 versus forecast hour. The statistics are averaged for surface pressure, 2-m temperature, and 3-m wind speed for the 12 AWS sites shown in Fig. 1. The bias and rmse are normalized to 1 by dividing by the maximum bias or rmse in the sample (for bias, which can be negative, absolute values are used). The AWS sites are maintained by the University of Wisconsin-Madison Antarctic Meteorological Research Center; the observations are archived on their Web site (http://amrc.ssec.wisc.edu/aws). It is noteworthy that the data from these AWS sites are regularly assimilated into the model initial conditions; thus the model data are not completely independent of the AWS observations. Modeled near-surface temperatures and winds are adjusted from the lowest model half-sigma level to the nominal AWS instrument

TABLE 1. Bias, rmse, and correlation coefficient between the model and observations for all 6-hourly AMPS 3.3-km forecasts between Jun 2002-May 2003 vs forecast hour. The statistics are averaged for surface pressure, 2-m temperature, and 3-m wind speed for the 12 AWS sites shown in Fig. 1. The bias and rmse are normalized to 1 as described in the text.

\begin{tabular}{cccc}
\hline \hline Hour & Bias & Rmse & Correlation \\
\hline 0 & $-\bar{c}$ & $-\overline{90}$ & $-\overline{-}$ \\
6 & 0.59 & 0.80 & 0.72 \\
12 & 0.89 & 0.86 & 0.73 \\
18 & 0.80 & 0.87 & 0.72 \\
24 & 0.81 & 0.86 & 0.72 \\
30 & 0.75 & 0.89 & 0.69 \\
36 & 0.79 & 0.90 & \\
\hline
\end{tabular}


TABLE 2. Long-term observed, 2002-03 observed, and 2002-03 modeled means and anomalies of surface pressure (hPa), 2-m temperature $\left({ }^{\circ} \mathrm{C}\right), 3-\mathrm{m}$ wind speed $\left(\mathrm{m} \mathrm{s}^{-1}\right)$, precipitation $(\mathrm{mm})$, and cloud fraction $(\%)$. The surface pressure, 2-m temperature, and 3-m wind speed means are averaged over the 12 AWS sites shown in Fig. 1. The precipitation $(\mathrm{mm})$ and cloud fraction $(\%)$ means are for McMurdo. The long-term surface pressure, 2-m temperature, and 3-m wind speed observations are from the same 12 AWS sites and span 1990-99. The long-term precipitation observations span 1959-88 (Keys 1980). The long-term cloud fraction observations span 1994-2003 (compiled from the British Antarctic Survey database). The last column gives the correlation coefficients of the monthly means of modeled vs observed over the annual cycle for 2002-03.

\begin{tabular}{|c|c|c|c|c|c|c|c|c|}
\hline & & A & B & $\mathrm{C}$ & $(B-A)$ & $(C-B)$ & $(C-A)$ & \\
\hline Variable & Season & $\begin{array}{l}\text { Long-term } \\
\text { observed }\end{array}$ & $\begin{array}{l}2002-03 \\
\text { observed }\end{array}$ & $\begin{array}{l}2002-03 \\
\text { modeled }\end{array}$ & $\begin{array}{c}2002-03 \\
\text { observed } \\
\text { minus } \\
\text { long-term } \\
\text { observed }\end{array}$ & $\begin{array}{c}2002-03 \\
\text { modeled } \\
\text { minus } \\
2002-03 \\
\text { observed }\end{array}$ & $\begin{array}{c}2002-03 \\
\text { modeled } \\
\text { minus } \\
\text { long-term } \\
\text { observed }\end{array}$ & $\begin{array}{c}\text { Correlation } \\
\text { of 2002-03 } \\
\text { modeled } \\
\text { vs observed } \\
\text { monthly means }\end{array}$ \\
\hline $\begin{array}{l}\text { Surface pressure } \\
\quad(\mathrm{hPa})\end{array}$ & $\begin{array}{l}\text { Annual } \\
\text { JJA } \\
\text { SON } \\
\text { DJF } \\
\text { MAM }\end{array}$ & $\begin{array}{l}970.6 \\
974.1 \\
964.8 \\
972.4 \\
971.2\end{array}$ & $\begin{array}{l}975.3 \\
976.5 \\
976.3 \\
976.6 \\
971.8\end{array}$ & $\begin{array}{l}973.5 \\
975.9 \\
975.7 \\
974.5 \\
967.8\end{array}$ & $\begin{array}{r}4.7 \\
2.4 \\
11.6 \\
4.2 \\
0.5\end{array}$ & $\begin{array}{l}-1.8 \\
-0.6 \\
-0.6 \\
-2.2 \\
-3.9\end{array}$ & $\begin{array}{r}2.9 \\
1.8 \\
10.9 \\
2.1 \\
-3.4\end{array}$ & $\begin{array}{l}0.96 \\
- \\
- \\
-\end{array}$ \\
\hline $\begin{array}{l}\text { Temperature at } \\
\text { at } 2 \mathrm{~m}\left({ }^{\circ} \mathrm{C}\right)\end{array}$ & $\begin{array}{l}\text { Annual } \\
\text { JJA } \\
\text { SON } \\
\text { DJF } \\
\text { MAM }\end{array}$ & $\begin{array}{r}-20.7 \\
-29.0 \\
-19.6 \\
-7.7 \\
-26.6\end{array}$ & $\begin{array}{r}-21.0 \\
-33.6 \\
-19.2 \\
-7.1 \\
-24.1\end{array}$ & $\begin{array}{r}-19.7 \\
-29.7 \\
-18.7 \\
-8.7 \\
-21.8\end{array}$ & $\begin{array}{r}-0.3 \\
-4.6 \\
0.4 \\
0.7 \\
2.5\end{array}$ & $\begin{array}{r}1.3 \\
3.9 \\
0.5 \\
-1.6 \\
2.4\end{array}$ & $\begin{array}{r}1.0 \\
-0.7 \\
0.9 \\
-0.9 \\
4.8\end{array}$ & $\begin{array}{l}1.00 \\
- \\
- \\
-\end{array}$ \\
\hline $\begin{array}{l}\text { Wind speed at } \\
3 \mathrm{~m}\left(\mathrm{~m} \mathrm{~s}^{-1}\right)\end{array}$ & $\begin{array}{l}\text { Annual } \\
\text { JJA } \\
\text { SON } \\
\text { DJF } \\
\text { MAM }\end{array}$ & $\begin{array}{l}5.2 \\
5.7 \\
5.7 \\
4.2 \\
5.0\end{array}$ & $\begin{array}{l}4.1 \\
3.7 \\
4.5 \\
3.7 \\
4.7\end{array}$ & $\begin{array}{l}6.8 \\
7.3 \\
6.6 \\
5.1 \\
8.0\end{array}$ & $\begin{array}{l}-1.0 \\
-2.0 \\
-1.2 \\
-0.5 \\
-0.3\end{array}$ & $\begin{array}{l}2.6 \\
3.6 \\
2.2 \\
1.3 \\
3.3\end{array}$ & $\begin{array}{l}1.6 \\
1.6 \\
0.9 \\
0.9 \\
3.0\end{array}$ & $\begin{array}{l}0.75 \\
- \\
- \\
-\end{array}$ \\
\hline $\begin{array}{l}\text { Precipitation } \\
\text { mount }(\mathrm{mm})\end{array}$ & $\begin{array}{l}\text { Annual } \\
\text { JJA } \\
\text { SON } \\
\text { DJF } \\
\text { MAM }\end{array}$ & $\begin{array}{r}184 \\
48 \\
40 \\
47 \\
50\end{array}$ & $\begin{array}{r}129 \\
16 \\
41 \\
33 \\
39\end{array}$ & $\begin{array}{r}186 \\
17 \\
31 \\
61 \\
77\end{array}$ & $\begin{array}{r}-55 \\
-32 \\
2 \\
-14 \\
-10\end{array}$ & $\begin{array}{r}56 \\
1 \\
-10 \\
28 \\
37\end{array}$ & $\begin{array}{r}2 \\
-31 \\
-8 \\
14 \\
27\end{array}$ & $\begin{array}{l}0.37 \\
- \\
- \\
-\end{array}$ \\
\hline $\begin{array}{l}\text { Cloud fraction } \\
(\%)\end{array}$ & $\begin{array}{l}\text { Annual } \\
\text { JJA } \\
\text { SON } \\
\text { DJF } \\
\text { MAM }\end{array}$ & $\begin{array}{l}61 \\
70 \\
54 \\
52 \\
67\end{array}$ & $\begin{array}{l}63 \\
40 \\
75 \\
76 \\
62\end{array}$ & $\begin{array}{l}50 \\
37 \\
49 \\
50 \\
66\end{array}$ & $\begin{array}{r}2 \\
-30 \\
20 \\
24 \\
-5\end{array}$ & $\begin{array}{r}-13 \\
-3 \\
-26 \\
-27 \\
4\end{array}$ & $\begin{array}{r}-10 \\
-33 \\
-5 \\
-3 \\
0\end{array}$ & $\begin{array}{l}0.35 \\
- \\
- \\
-\end{array}$ \\
\hline
\end{tabular}

heights of $2 \mathrm{~m}$ (temperature) and $3 \mathrm{~m}$ (winds) using Monin-Obukhov similarity theory (Stull 1988). Table 1 indicates that there are only small changes in the statistics over the length of the forecast. The bias is even smaller at hours 30 and 36 than at hours 12 and 18 (this was also found by Bromwich et al. (2005), who attributed this to deficiencies in the initial conditions). Therefore, we consider the 24-33-h forecasts to be adequate for use in this study. In the next section, we evaluate how well 2002-03 represents the mean climatological conditions in the McMurdo region.

\section{Comparison of modeled and observed fields}

Table 2 compares the long-term observed, 2002-03 observed, and 2002-03 modeled means and anomalies of several atmospheric variables. The stations, data sources, and periods over which the long-term means are averaged are given in the caption. The results are shown for the annual and seasonal means [winter: June-August (JJA); spring: September-November
(SON); summer: December-February (DJF); fall: March-May (MAM)]. An exhaustive description of the results in Table 2 will not be given here. Rather, the most important results are discussed and otherwise the reader can refer to Table 2 as necessary when interpreting the 2002-03 modeled climatalogical fields (presented in Figs. 3-7 in section 4).

Column B - A in Table 2 shows the 2002-03 observed minus the long-term observed. This column gives an estimate of how typical this season was with respect to long-term observations. Surface pressure was higher than normal throughout 2002-03, suggesting less synoptic activity in the region than is normal. This is corroborated by the precipitation anomalies in the same column, which indicate precipitation is lower than normal for the year, and for all seasons except springtime. This is ironic because the pressure in springtime is especially high. Closer inspection reveals that this is mainly due to an anomalous October (not shown) in which the surface pressure was about $20 \mathrm{hPa}$ greater than normal; the bulk of the springtime precipitation 
came in September and November when the surface pressure was closer to normal. The near-surface temperature is nearly normal for the annual mean, but is $-4.5^{\circ}$ colder than normal during winter and slightly warmer than normal in autumn. The wind speed is about $1 \mathrm{~m} \mathrm{~s}^{-1}$ weaker than normal for the annual mean and is negative in all seasons. The largest anomaly occurs in winter, perhaps related to the colder-than-normal temperatures. Taken together, the anomalies suggest a stronger-than-normal temperature inversion hindered higher momentum air aloft from mixing downward. The cloud fraction is about normal for the annual mean, but the seasonal anomalies are rather large. Some of the anomalies may be due in part to the mild El Niño conditions persisting during June 2002-May 2003.

Column C - B of Table 2 shows the 2002-03 modeled minus 2002-03 observed. This column indicates how the model is biased compared to observations. The surface pressure biases become increasingly negative from SON through MAM. This is related to a change in the digital elevation model used for terrain on the coarser-resolution $30-\mathrm{km}$ domain in November 2002; closer inspection (not shown) indicates the change has little impact on the temperature and winds. A warm temperature bias is present in the coldest months. This may be related to the modeled wind speed for which there is a positive bias throughout the year, especially in the colder months. Bromwich et al. (2005) suggest that the modeled winds are likely causing too much downward mixing of warmer air aloft, weakening the strong near-surface inversion. Ironically, this tends to counteract the anomalously cold winter temperatures and weaker than normal winds indicated in the paragraph above for the JJA 2002 observations, resulting in the model fields having smaller winter biases of temperature and wind speed with respect to the long-term observations (see column $\mathrm{C}-\mathrm{A}$ ). Wind direction (not shown here) is well captured in AMPS; the biases in direction are less than $10^{\circ}$ throughout the year.

Column $\mathrm{C}-\mathrm{B}$ indicates the AMPS annual mean precipitation for 2002-03 at McMurdo is about $56 \mathrm{~mm}$ (44\%) higher than that observed for the same period. This is mainly due to overestimated precipitation in summer and autumn, which may be related to the increasingly negative surface pressure bias from SON through MAM noted above. In addition, these are the seasons with the greatest fraction of open water in the Ross Sea; thus, it is possible the model may be overestimating the supply of available moisture (perhaps partly due to not resolving Iceberg B-15A). It is also noteworthy that the precipitation gradient in the vicinity of McMurdo is very sharp. Modeled precipitation amounts change substantially by shifting a few grid points in the east-west direction. Finally, the 200-mm nipher shielded gauge at McMurdo is in a localized lee area, which likely receives less snow than its surroundings (A. Cayette, Aviation Technical Services, 2003, personal communication) and it is unlikely that this is resolved by AMPS. Therefore, discrepancies between modeled and observed precipitation may not be as marked as they appear in Table 2.

The simulated cloud fraction at McMurdo for 200203 is approximately correct for winter and autumn, but is underestimated over the annual mean and for spring and summer. Bromwich et al. (2005) also found that the cloud fraction was generally underestimated by AMPS and attributed this to the selection of longwave absorption coefficients in the equation for cloud optical depth from which cloud fraction is estimated in Polar MM5. Despite this shortcoming, Bromwich et al. (2005) noted surprisingly good correlations with observed fields, suggesting this method provides a reasonable estimate of cloud variability in space and time.

Column C - A in Table 2 shows the 2002-03 modeled minus long-term observed. The numbers in this column take into account the model biases, so they give an estimate of how representative the model fields are of long-term climate. There is a large surface pressure anomaly that is still present in SON after considering the model bias. The temperature biases are $1^{\circ} \mathrm{C}$ or less except in MAM, which exhibits a $4.8^{\circ} \mathrm{C}$ warm bias. There is a positive wind speed anomaly over the entire annual cycle that is largest in MAM $\left(3 \mathrm{~m} \mathrm{~s}^{-1}\right)$ The annual precipitation at McMurdo is nearly identical to the long-term mean, but there is a large negative (positive) anomaly in JJA (MAM). Cloud fraction anomalies are less than $10 \%$ except in JJA.

The final column in Table 2 indicates that monthly variability is well captured for temperature and pressure, and reasonably well captured for the wind speed; correlation coefficients are $r=0.96$ (surface pressure), $r$; 1.0 (2-m temperature), and $r=0.75$ (wind speed). The spatial distribution of the surface pressure, temperature, and winds (shown in section 4) compares well with previous observationally based climatologies (e.g., Bromwich 1991, Fig. 9). The precipitation and cloud fraction are captured with less skill $(r=0.37$ and 0.35 , respectively). Considering the episodic nature of these variables, the uncertainties involved in their measurement and that they are compared to observations at only one site, the model depiction of precipitation and cloud fraction is as good as can be expected. With the exception of SON surface pressure, it is not clear whether the anomalies exceed the range of internal variability of the model and measurement uncertainties. Thus, the fields are presented in section 4 without adjustment with the exception of SON MSLP, which has been adjusted by subtracting $10 \mathrm{hPa}$ uniformly from the entire field. When inspecting the figures, the reader may wish to consult Table 2 to consider the anomalies and biases discussed here.

\section{Climatology of the McMurdo region}

Figure 3 shows the annual and seasonal AMPS 3.3$\mathrm{km}$ domain 24-33-h 3-m vector mean wind directions 
a) ANNUAL
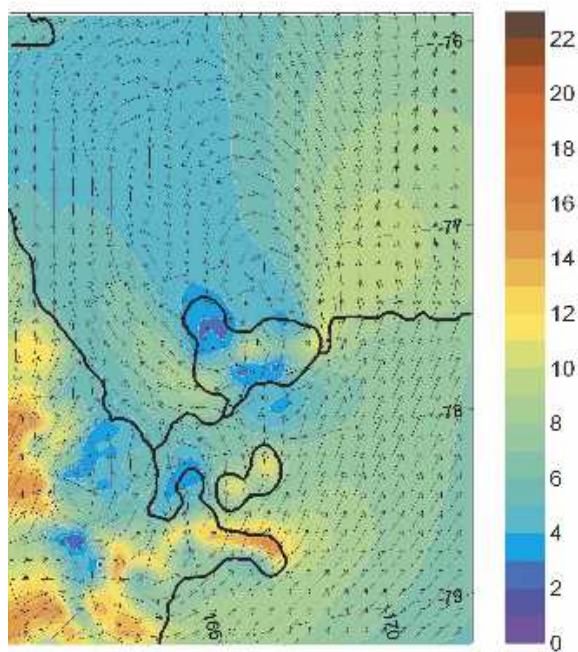

b) JJA 2002

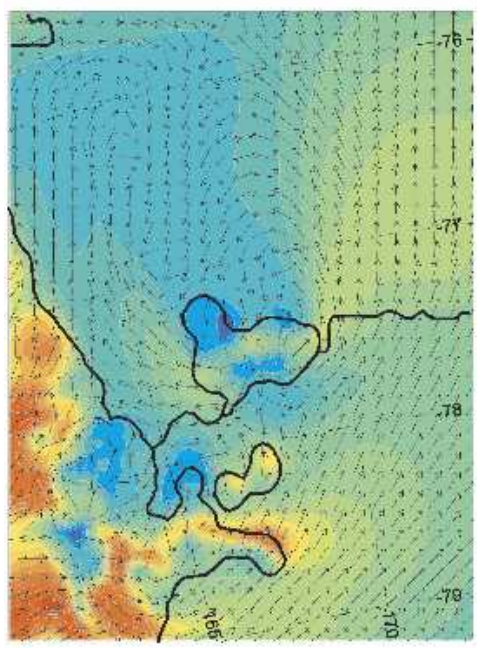

d) DJF 2002-03

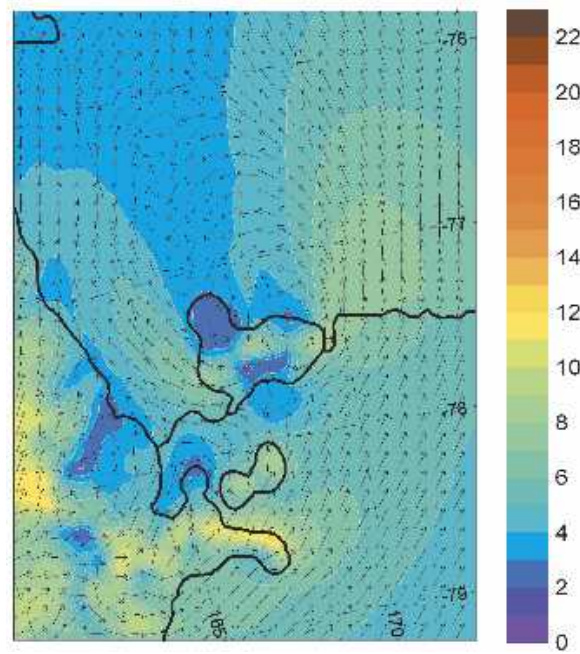

c) SON 2002

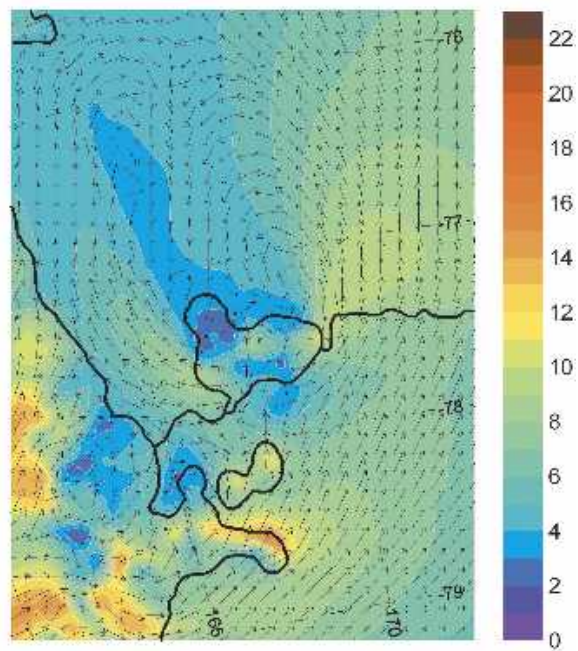

\section{e) MAM 2003}

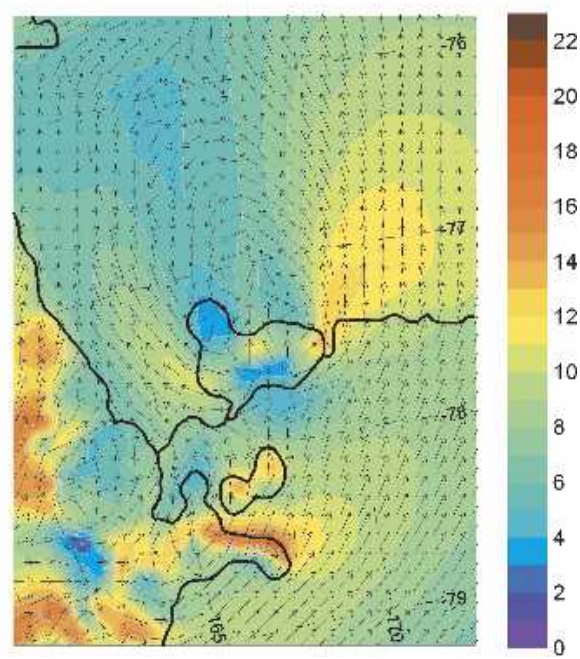

FIG. 3. AMPS 3.3-km domain 24-33-h 3-m winds. Arrows show vector-mean direction and colors show scalar average wind speed $\left(\mathrm{m} \mathrm{s}^{-1}\right.$ ) for (a) the annual mean (Jun 2002-May 2003), (b) JJA 2002, (c) SON 2002, (d) DJF 2002-03, and (e) MAM 2003. 
and mean scalar wind speeds for June 2002-May 2003 for the annual, winter, spring, summer, and autumn cases. Over the annual mean, the dominance of southerly flow and the blocking effect of Ross Island are evident. Flow splitting around Ross Island, as discussed by Seefeldt et al. (2003), is also captured. Easterly winds, similar to those observed (Sinclair 1982; Stearns 1997), are simulated in the vicinity of McMurdo and Williams Field runway (location shown in Fig. 1). Winds are slower in the lee (north) of the island, and there are discernable quasi-permanent vorticies due to vortex shedding of the flow around the topography (Powers et al. 2003). These may be partly responsible for the high incidence of mesoscale cyclogenesis observed to the north of the island (Carrasco et al. 2003). The majority of the flow is diverted around the east side of the island and generates the Ross Sea polynya, an important source of Antarctic Bottom Water (e.g., Zwally et al. 1985). The highest wind speeds are in the mountain valleys to the west of Ross Island; inspection of the seasonal means indicates these are greatest in winter, an indication of their katabatic origin. The winds converge and speed up on the lee slopes of the smaller topographic features such as Minna Bluff and Black and White Islands. Inspection of the seasonal means indicates that the MAM (autumn) 2003 winds were slightly stronger than those in JJA (winter) 2002 in the low-lying areas. This may be in part due to the atypical synoptic conditions in autumn 2003 discussed in the previous section. The weakest winds occur in summer due to slackened pressure and temperature gradients; the departures from the windier seasons are most marked in the Transantarctic Mountains, to the south of Minna Bluff, and to the northeast of Ross Island.

Figure 4 shows the 2-m temperature. In addition to variability due to elevation, marked horizontal temperature gradients are also evident. A sharp temperature gradient is apparent within a few tens of kilometers of the ice shelf edge to the east of Ross Island and is steepest in winter when the air - sea temperature contrast is greatest. Warm signatures are present in the McMurdo Dry Valleys, especially in winter, evidence of vertical mixing due to katabatic winds. In addition, a "hot spot" is evident at the mouth of Taylor and Ferrar Valleys (see Fig. 1 for location); this may be related to the convergence of air splitting westward around Ross Island (i.e., Fig. 3) with eastward air that flows down Ferrar and Taylor Valleys. The convergence may cause rising motion and thus a region of enhanced cloud cover (evident in Fig. 7, discussed later) that in turn warms the surface due to downwelling longwave radiation. In all seasons, a tongue of relatively warm air due to McMurdo Sound extends around the west side of Ross Island and penetrates onto the ice shelf. Its effect decreases rapidly inland of Black and White Islands and Minna Bluff, where the colder southerly winds are more influential. It is likely that the blocking of the wind around these terrain features causes the northwest to southeast orientation of the temperature gradient on the ice shelf (noted earlier by Savage and Stearns 1985). Similar to that suggested by Bromwich et al. (1992), it appears that the relatively warm winters at McMurdo are due to the regional topography steering the bulk of the cold southerly winds from the Ross Ice Shelf to the east of Ross Island. The largest annual cycle of temperature is in the southeast corner of the domain, farthest from the marine influence.

Figure 5 shows the MSLP. Areas above $500 \mathrm{~m}$ are masked due to the difficulties associated with calculating MSLP over high, cold terrain. In all seasons, the effects of topography are well marked. The SON values in Fig. 5 have been adjusted by $-10 \mathrm{hPa}$ to account for the anomalies from the long-term mean discussed in section 3 (Table 2). In this manner, SON is more representative of mean climatological conditions. This allows the signature of the semiannual surface pressure oscillation noted by van Loon (1967) to be distinguished; that is, the highest MSLP in the south polar region occurs twice per year in summer and winter, near the solstices. The lowest atmospheric pressure occurs in the spring and autumn seasons due to meridional migrations of the circumpolar trough surrounding Antarctica. A localized area of high (low) pressure is present on the windward (leeward) side of Ross Island due to the flow separation around this obstacle. The high pressure to the south of the island is likely an important contributor to the frequent occurrence of fog at Williams Field (A. Cayette, Aviation Technical Services, 2003, personal communication). Similarly, localized high pressure occurs on the windward side of Minna Bluff, supporting the flow diversion to the east of the obstacle that is evident in Fig. 3. The area of lowest MSLP is in the northeast corner of the domain where the effects of large synoptic systems entering the Ross Sea are prominent (Simmonds et al. 2003). A smaller minimum is present in the southeast corner of the domain for the same reason; the large synoptic systems that enter the Ross Sea from the north often move onto the ice shelf. Ridging is evident on the Ross Ice Shelf along the Transantarctic Mountains due to damming of the flow from these systems by the terrain, similar to the cold-air damming observed along the eastern side of the Appalachian Mountains in the United States (Bell and Bosart 1988). The resulting pressure gradient normal to the mountains drives the persistent southerly barrier wind regime (O'Connor et al. 1994).

Figure 6 shows the precipitation amount (water equivalent). Inspection of Fig. 6 indicates strong forcing by the terrain. Orographic maxima occur on the southerly slopes of the mountains, consistent with the dominantly southerly flow regime. A strong precipitation shadow effect is apparent to the north of the mountains in the southwest corner of the domain; this appears to exert an important influence on the low precipitation 
a) ANNUAL

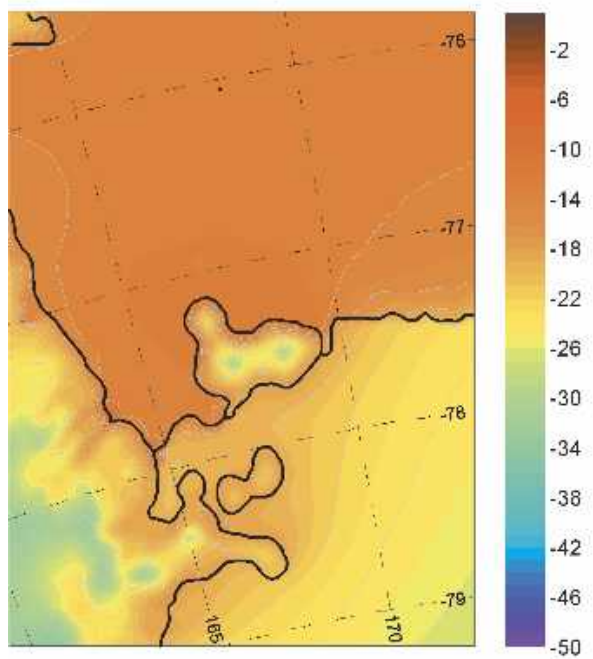

b) JJA 2002

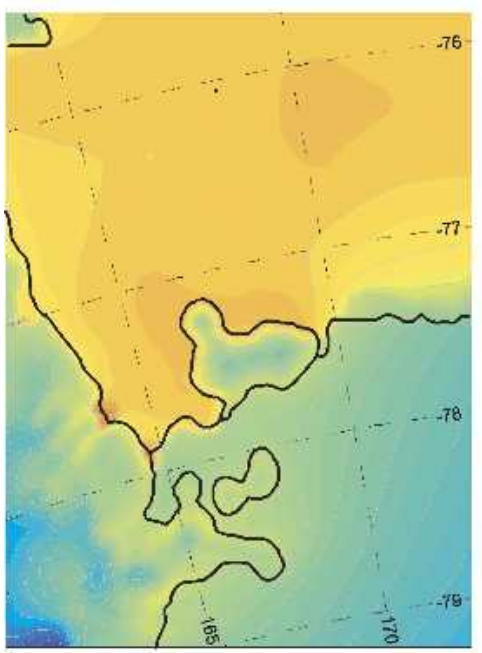

d) DJF 2002-03

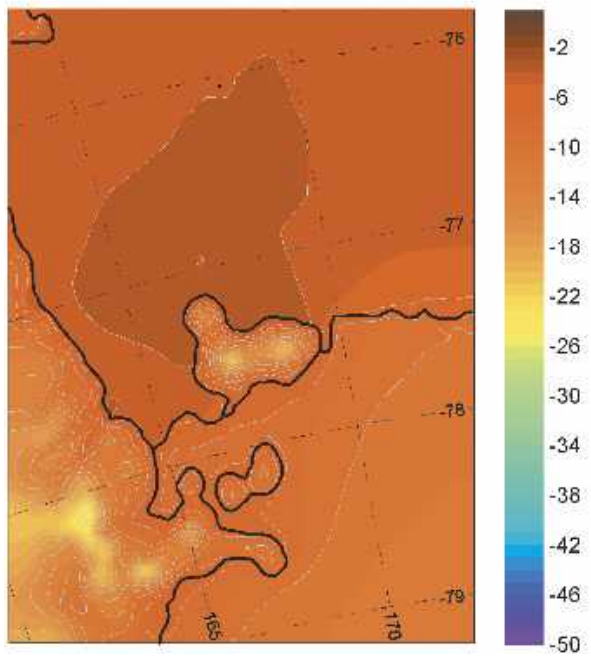

\section{c) SON 2002}
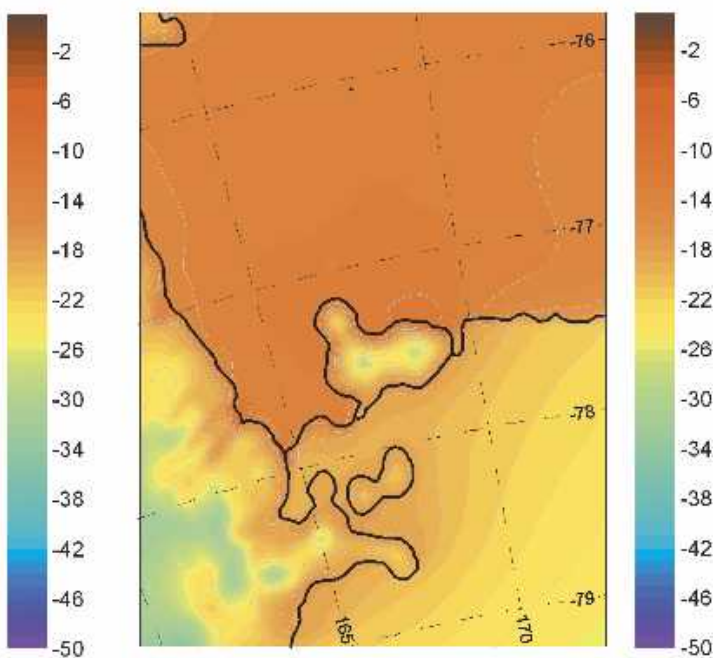

e) MAM 2003

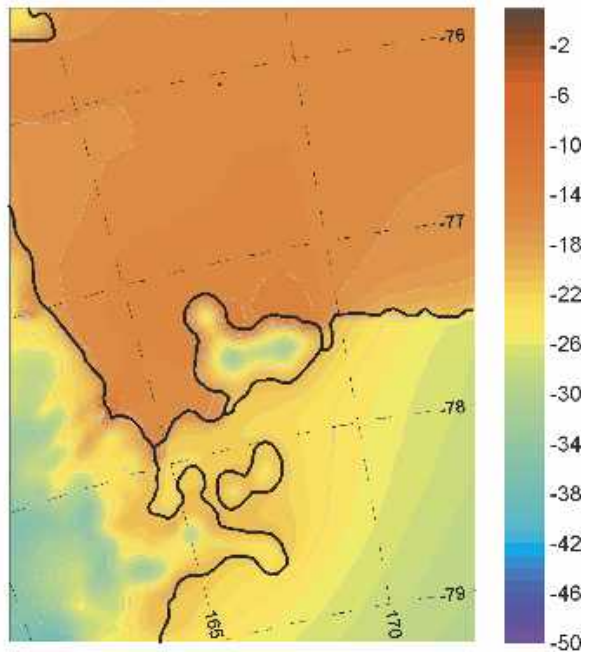

FIG. 4. AMPS 3.3-km domain 24-33-h 2-m temperature $\left({ }^{\circ} \mathrm{C}\right)$ for (a) the annual mean (Jun 2002-May 2003), (b) JJA 2002, (c) SON 2002, (d) DJF 2002-03, and (e) MAM 2003. 
a) ANNUAL

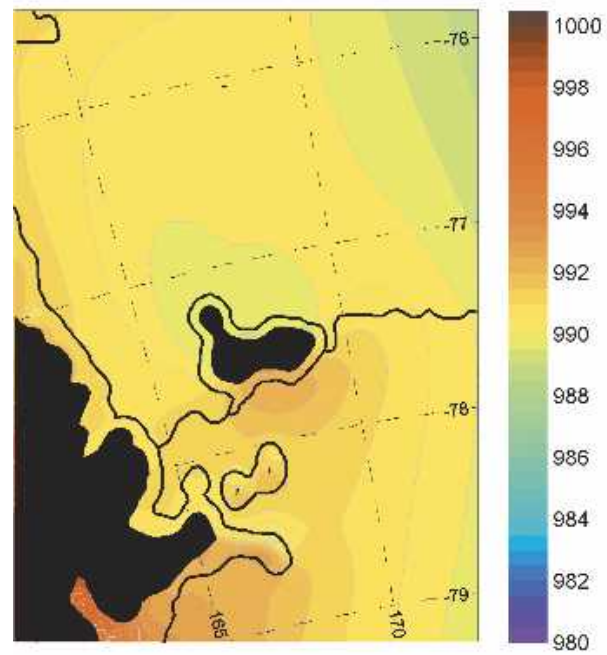

b) JJA 2002

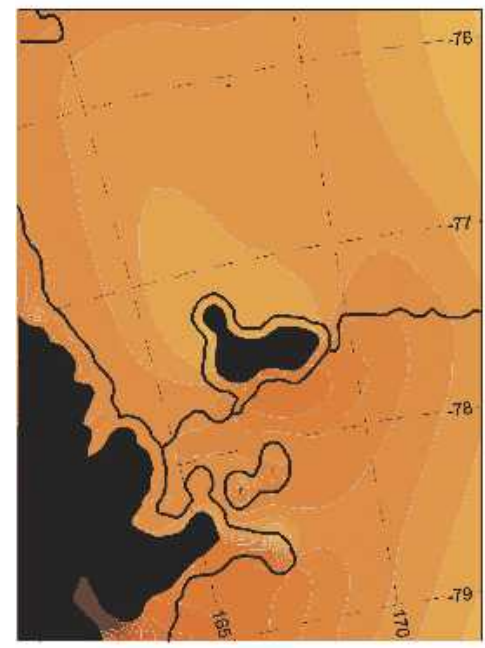

d) DJF 2002-03

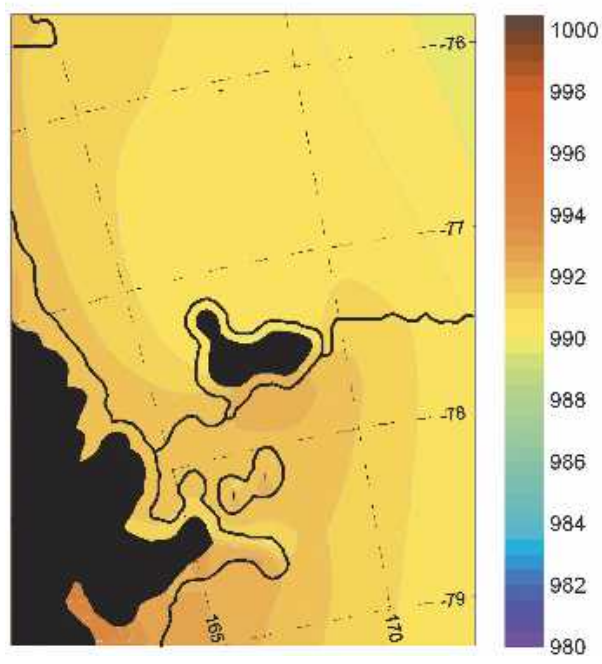

c) SON 2002 (Adjusted)

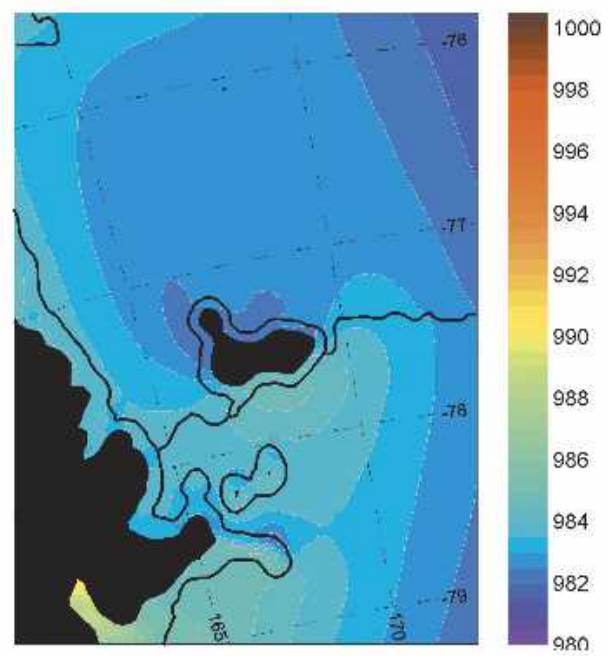

e) MAM 2003

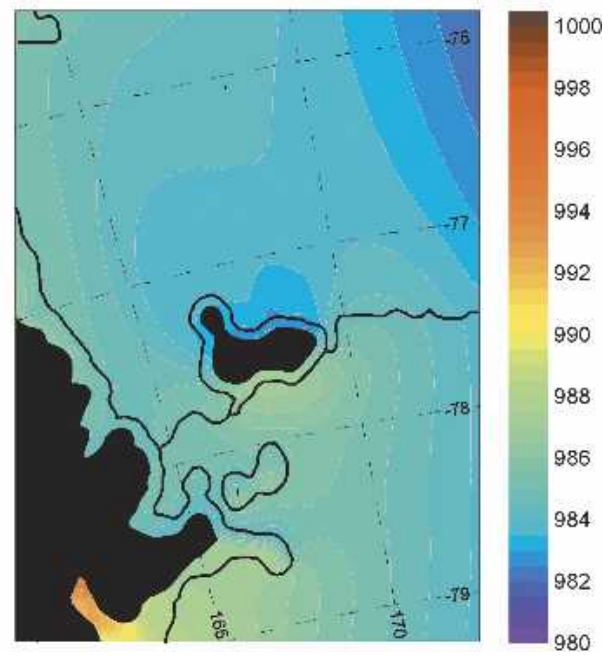

FIG. 5. AMPS 3.3-km domain 24-33-h MSLP (hPa) for (a) the annual mean (Jun 2002-May 2003), (b) JJA 2002, (c) SON 2002, (d) DJF 2002-03, and (e) MAM 2003. The SON values have been adjusted by $-10 \mathrm{hPa}$, as explained in the text. 
a) ANNUAL

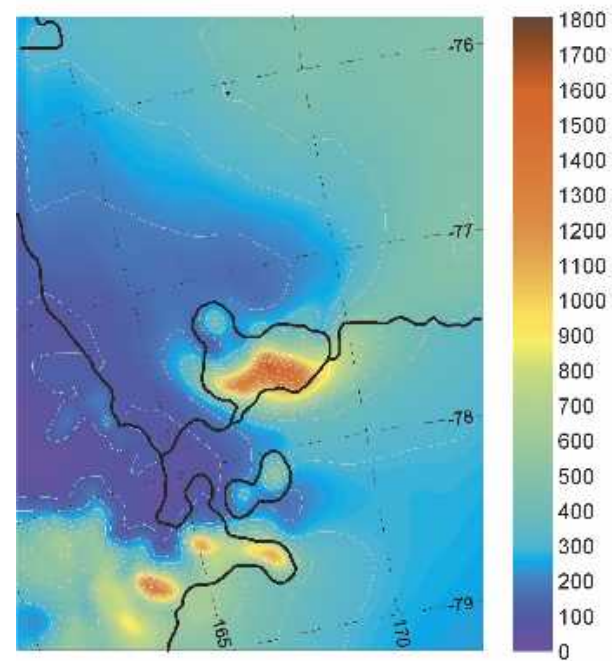

b) JJA 2002
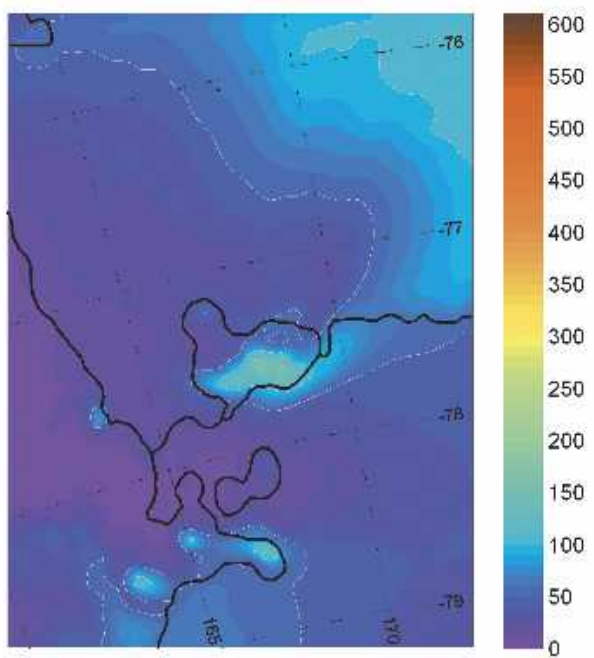

d) DJF 2002-03

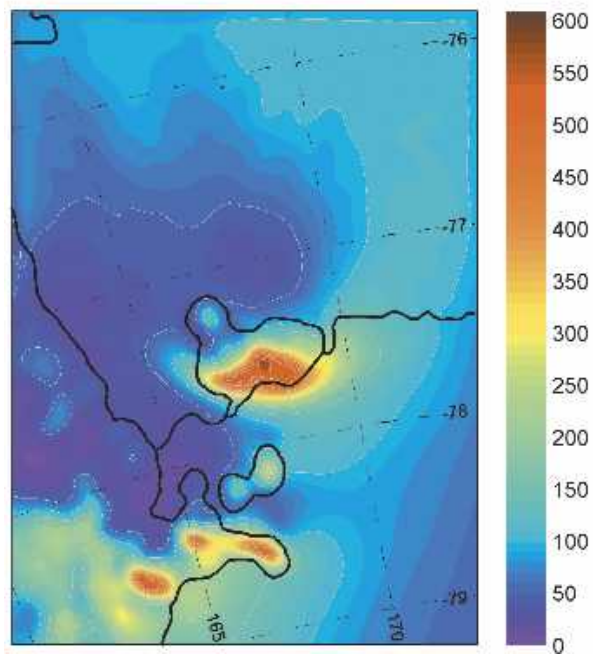

c) SON 2002

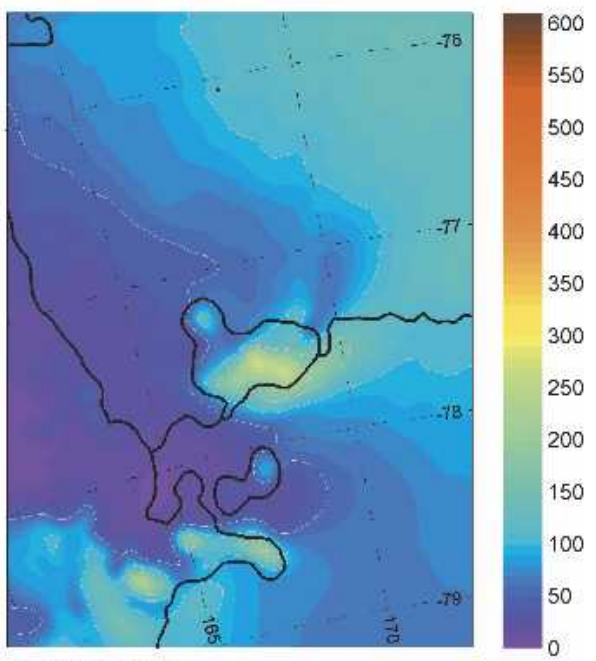

e) MAM 2003

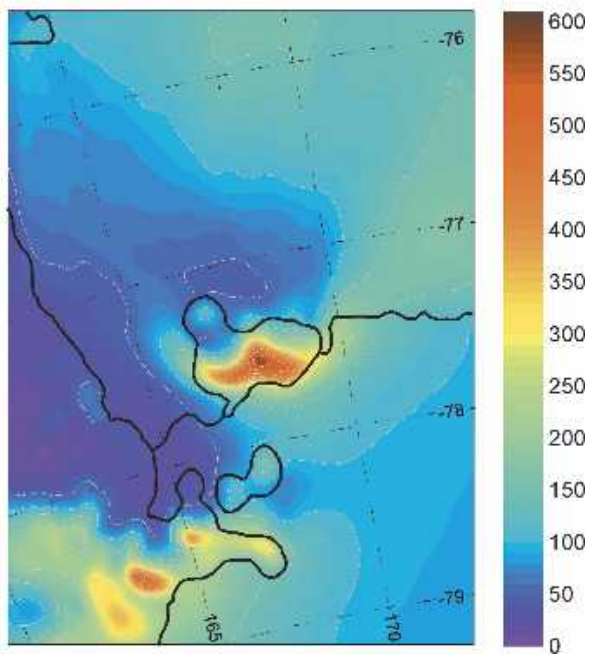

FIG. 6. AMPS 3.3-km domain 24-33-h precipitation (mm water equivalent) for (a) the annual mean (Jun 2002-May 2003), (b) JJA 2002, (c) SON 2002, (d) DJF 2002-03, and (e) MAM 2003. Note that the annual scale is different from the seasonal scale. 
accumulation observed in the McMurdo Dry Valleys (e.g., Bull 1966). An axis of higher precipitation amounts "wraps" around Ross Island from the northeast, indicating that the large synoptic systems that pass to the northeast and east of Ross Island (Simmonds et al. 2003) are the primary sources of precipitation along its slopes. This is due to the orography of Ross Island uplifting the northward flow generated on the western side of these cyclones. It appears that the precipitation maximum located in the southwest corner of the domain is also largely due to these synoptic systems; in this case the precipitation may be related to the cyclonically forced barrier winds that are set up parallel to the Transantarctic Mountains and flow northward (O'Connor et al. 1994). Winter and spring are the driest seasons, while summer and autumn are wetter. Furthermore, the major interseasonal variability occurs in the mountains; there is much less variability at low elevations and over the ice shelf. From the comparisons of simulated and observed precipitation shown in Table 2 for McMurdo, it should be considered that the model may be slightly wetter than typical in the summer and autumn and drier than typical in the winter; that is, the amplitude of the simulated seasonal precipitation cycle may be overestimated by AMPS.

Figure 7 shows the cloud fraction. Inspection indicates that cloudiness is dominated by the amount of open water in the Ross Sea to the north. Over the annual cycle and in all seasons, the cloudiest region is to the northeast of Ross Island in the vicinity of the Ross Sea polynya where open water occurs nearly yearround, largely due to persistent southerly winds (Fig. 3; e.g., Bromwich et al. 1998). The spatial and temporal distribution of the clouds closely follows the precipitation patterns. Temporally, the lowest instances of cloudiness occur in winter and spring, while the highest instances of cloudiness occur in summer and autumn. Spatially, areas of high cloudiness are present over Ross Island and on the south slopes of the mountains in the southwest corner of the domain, while lower cloudiness occurs over the McMurdo Dry Valleys and along the Victoria Land coast. Sinclair (1982) also noted lower cloud amounts along the Victoria Land coast based on observations; temporary field camps on the sea ice and permanent ice to the west and southwest of Ross Island were generally less cloudy than McMurdo. He speculated that this was due to the katabatic influence from the mountain valleys to the west. A small area of high cloudiness is present at the mouth of Taylor and Ferrar Valleys near the hot spot noted in Fig. 4, which further suggests that convergence is occurring there.

\section{Conclusions}

This study employs a relatively new resource to explore the seasonal and annual climatology of the McMurdo region with high spatial resolution. Twice-daily forecasts from the $3.3-\mathrm{km}$ resolution domain of the Antarctic Mesoscale Prediction System are joined together to construct this climatology for one annual cycle from June 2002 to May 2003. The results demonstrate the first-order importance of terrain in shaping the regional climate and emphasize the complex meteorological interactions that arise at the confluence of the plateau, ice shelf, and the ocean environments.

To the authors' knowledge, this is the first time a high-resolution climatology of the McMurdo region from a physically based numerical weather prediction model adapted for polar regions has been constructed. By comparing the annual and seasonal wind, temperature, pressure, precipitation, and cloud fraction fields side by side, important aspects of the regional climate have been studied in greater detail than previously possible. For example, the McMurdo Dry Valleys are the largest ice free area in Antarctica (Doran et al. 2002). It has been surmised that this is due to 1) topographic obstructions at the west ends of the valleys where they meet the East Antarctic ice sheet, 2) low annual snowfall, 3) the frequent removal of snowfall by strong winds, and 4) a persistent dry foehn wind regime due to the valleys' lower elevation with respect to the East Antarctic ice sheet (Riordan 1975). However, the cause of the low annual snowfall in the dry valleys has never been identified. Our results indicate that this is due to a precipitation shadow effect caused by the mountains to the south. In addition, climatological eddies in the simulated wind field to the north of Ross Island suggest that the shedding of vortices as a result of airflow separation around the island plays an important role in the frequent mesoscale cyclogenesis observed in that area.

Another motivation for this study is to fill the inevitable data voids remaining from previous observationally based climatologies. For some fields, these are extensive; for example, year-round precipitation observations are only available from McMurdo. Thus, the firstever detailed maps of the regional precipitation distribution are presented. Some potential applications of the climatological maps include operational and field planning; for example, the maps may aid in selecting sites for the impending Antarctic Regional Interactions Meteorology Experiment (RIME), a field program planned under the auspices of the U.S. National Science Foundation that has the goal of understanding in more detail the role of Antarctica in the global climate system (Bromwich and Parish 2002).

As the AMPS forecasts and the associated archive continue to mature, it will become possible construct a more accurate climatology of the region and to assess interannual variability. A climate database, more easily accessible to the broader scientific community than the archived raw forecasts, will soon be available. This database may prove practical for more detailed and interdisciplinary studies than that presented here. One example is an in-depth examination of the McMurdo Dry Valleys, which is planned for the future. This study 
a) ANNUAL

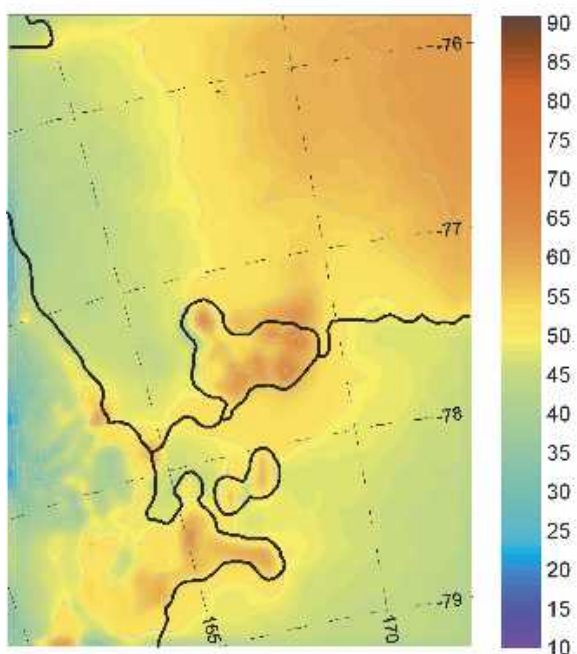

b) JJA 2002
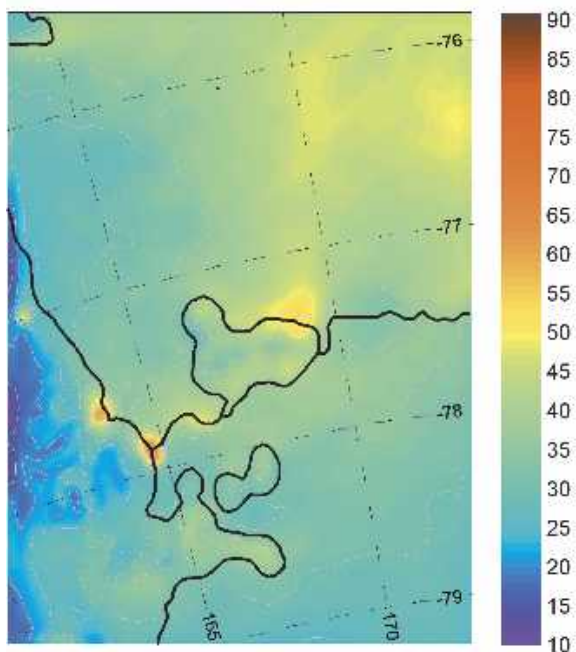

d) DJF 2002-03

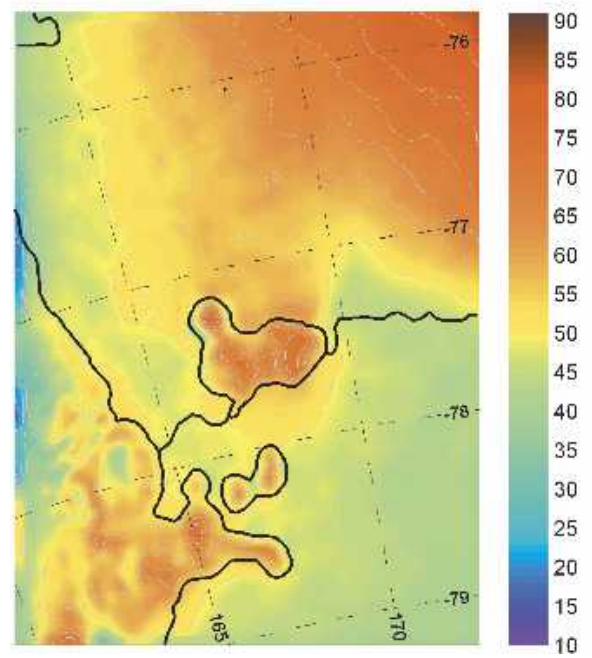

FIG. 7. AMPS 3.3-km domain 24-33-h cloud fraction (\%) for (a) the annual mean (Jun 2002-May 2003), (b) JJA 2002, (c) SON 2002, (d) DJF 2002-03, and (e) MAM 2003.

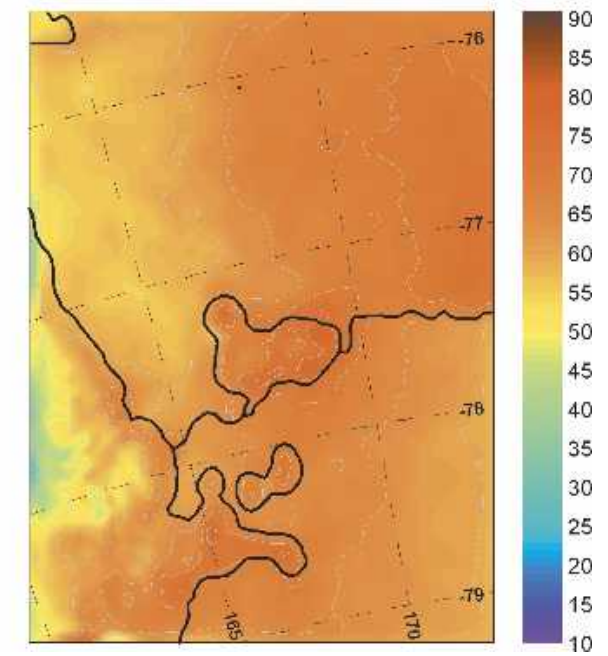

\section{c) SON 2002}

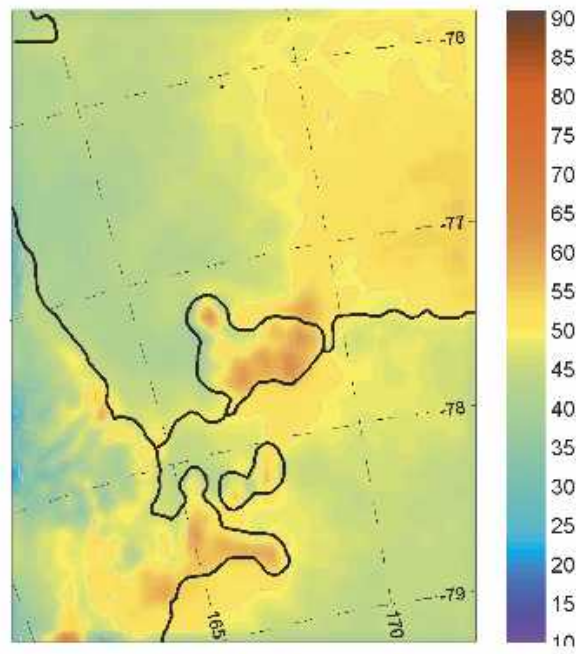

e) MAM 2003 
could potentially benefit biologists, geologists, and paleoclimatologists as they endeavor to understand the unique ecosystem of the dry valleys. Finally, additional model domains included in the database may facilitate studies of other parts of Antarctica, such as the recently implemented 10-km domain over the Antarctic Peninsula.

Acknowledgments. This research was supported by the National Science Foundation, Office of Polar Programs (UCAR Subcontract SO1-22961) and the National Aeronautics and Space Administration (Grant NAG5-9518). Observations were obtained from the Antarctic Meteorological Research Center at the University of Wisconsin-Madison (Matthew Lazzara) and the British Antarctic Survey (Steve Colwell). Archived AMPS forecasts were obtained from the NCAR Scientific Computing Division's Data Support Section. Gratitude is due to Mr. Arthur Cayette of the Space and Naval Warfare Systems Center, Charleston, South Carolina, for lending his invaluable knowledge of McMurdo weather and climate based on over 20 years of forecasting experience.

\section{REFERENCES}

Armstrong, T., B. Roberts, and C. Swithinbank, 1973: Illustrated Glossary of Snow and Ice. Scott Polar Research Institute, 60 pp.

Bell, G. D., and L. F. Bosart, 1988: Appalachian cold-air damming. Mon. Wea. Rev., 116, 137-161.

Bromwich, D. H., 1988a: A satellite study of barrier-wind airflow around Ross Island. Antarct. J. U.S., 23, 167-169.

_ 1988b: Snowfall at high southern latitudes. Rev. Geophys., 26, 149-168.

__ 1989: Satellite analyses of Antarctic katabatic wind behavior. Bull. Amer. Meteor. Soc., 70, 738-749.

_ 1991: Mesoscale cyclogenesis over the southwestern Ross Sea linked to strong katabatic winds. Mon. Wea. Rev., 119, 1736-1752.

_, and T. R. Parish, Eds., 2002: Scientific motivation for the Ross Island Meteorology Experiment (RIME). BPRC Miscellaneous Series M-425, Byrd Polar Research Center, The Ohio State University, Columbus, OH, 14 pp.

— , J. F. Carrasco, and C. R. Stearns, 1992: Satellite observations of katabatic wind propagation for great distances across the Ross Ice Shelf. Mon. Wea. Rev., 120, 1940-1949.

_ , Z. Liu, A. N. Rogers, and M. L. Van Woert, 1998: Winter atmospheric forcing of the Ross Sea Polynya. Ocean, Ice and Atmosphere: Interactions at the Antarctic Continental Margin, S. S. Jacobs and R. Weiss, Eds., Antarctic Research Series, Vol. 75, Amer. Geophys. Union, 101-133.

_ _ J. J. Cassano, T. Klein, G. Heinemann, K. M. Hines, K. Steffen, and J. E. Box, 2001: Mesoscale modeling of katabatic winds over Greenland with the Polar MM5. Mon. Wea. Rev., 129, 2290-2309.

_ A. J. Monaghan, J. G. Powers, J. J. Cassano, H. Wei, Y. Kuo, and A. Pellegrini, 2003: Antarctic Mesoscale Prediction System (AMPS): A case study from the 2000/2001 field season. Mon. Wea. Rev., 131, 412-434.

,,$---\longrightarrow$, and K. W. Manning, 2005: Real-time forecasting for the Antarctic: An evaluation of the Antarctic Mesoscale Prediction System (AMPS). Mon. Wea. Rev., 133, 579-603.

Bull, C., 1966: Climatological observations in ice-free areas of southern Victoria Land, Antarctica. Studies in Antarctic Me- teorology, M. J. Rubin, Ed., Antarctic Research Series, Vol. 9, Amer. Geophys. Union, 177-194.

Carrasco, J. F., and D. H. Bromwich, 1994: Climatological aspects of mesoscale cyclogenesis over the Ross Sea and Ross Ice Shelf regions of Antarctica. Mon. Wea. Rev., 122, 2405-2425. , and _ 1996: Mesoscale cyclone activity near Terra Nova Bay and Byrd Glacier, Antarctica during 1991. Global Atmos. Ocean Syst., 5, 43-72.

$\longrightarrow,-$, and A. J. Monaghan, 2003: Distribution and characteristics of mesoscale cyclones in the Antarctic: Ross Sea eastward to the Weddell Sea. Mon. Wea. Rev., 131, 289-301.

Cassano, J. J., J. E. Box, D. H. Bromwich, L. Li, and K. Steffen, 2001: Verification of Polar MM5 simulations of Greenland's atmospheric circulation. J. Geophys. Res., 106, 13 867-13 890.

Doran, P. T., C. P. McKay, G. D. Clow, G. L. Dana, A. G. Fountain, T. Nylen, and W. B. Lyons, 2002: Valley floor climate observations from the McMurdo Dry Valleys, Antarctica, 1986-2000. J. Geophys. Res., 107, 4772, doi:10.1029/ 2001JD002045.

Gallée, H., 1996: Mesoscale atmospheric circulations over the southwestern Ross Sea sector, Antarctica. J. Appl. Meteor., 35, 1129-1141.

Grell, G. L., J. Dudhia, and D. R. Stauffer, 1994: A description of the fifth-generation Penn State/NCAR mesoscale model (MM5). NCAR Tech. Note NCAR/TN-398+STR, 117 pp.

Guo, Z., D. H. Bromwich, and J. J. Cassano, 2003: Evaluation of Polar MM5 simulations of Antarctic atmospheric circulation. Mon. Wea. Rev., 131, 384-411.

Holmes, R., and C. R. Stearns, 1995: Use of automatic weather station data for forecasting high wind speed events at Pegasus Runway. Antarct. J. U.S., 30, 329-331.

,-- G. Weidner, and L. Keller, 2000: Utilization of automatic weather station data for forecasting high wind speed events at Pegasus Runway, Antarctica. Wea. Forecasting, 15, $137-151$.

Keys, J. R., 1980: Air temperature, wind, precipitation and atmospheric humidity in the McMurdo region. Department of Geology Publication 17, Antarctic Data Series 9, Victoria University, Wellington, New Zealand, $57 \mathrm{pp}$.

Liu, H., K. C. Jezek, and B. Li, 1999: Development of an Antarctic digital elevation model by integrating cartographic and remotely sensed data: A geographic information system based approach. J. Geophys. Res., 104, 23 199-23 213.

Mather, K. B., and G. S. Miller, 1967: Notes on topographic factors affecting the surface wind in Antarctica, with special reference to katabatic winds. University of Alaska Tech. Rep. U.A.G. R-189, 125 pp.

Monaghan, A. J., D. H. Bromwich, H. Wei, A. M. Cayette, J. G. Powers, Y. H. Kuo, and M. Lazzara, 2003: Performance of weather forecast models in the rescue of Dr. Ronald Shemenski from the South Pole in April 2001. Wea. Forecasting, 18, $142-160$.

National Antarctic Expedition, 1901-1904, 1908: Meteorology Part 1. Observations at Winter Quarters and on Sledge Journeys, with Discussions by Various Authors. Royal Society, 548 pp.

Nuss, W. A., and D. W. Titley, 1994: Use of multiquadric interpolation for meteorological objective analysis. Mon. Wea. Rev., 122, 1611-1631.

O'Connor, W. P., and D. H. Bromwich, 1988: Surface airflow around Windless Bight, Ross Island, Antarctica. Quart. J. Roy. Meteor. Soc., 114, 917-938.

— — , and J. F. Carraso, 1994: Cyclonically-forced barrier winds along the Transantarctic Mountains near Ross Island. Mon. Wea. Rev., 122, 137-150.

Powers, J. G., A. J. Monaghan, A. M. Cayette, D. H. Bromwich, Y.-H. Kuo, and K. W. Manning, 2003: Real-time mesoscale modeling over Antarctica: The Antarctic Mesoscale Prediction System (AMPS). Bull. Amer. Meteor. Soc., 84, 1533-1545. 
Riordan, A. J., 1975: The climate of Vanda Station, Antarctica. Climate of the Arctic, G. Weller and S. A. Bowling, Eds., Geophysical Institute, University of Alaska Fairbanks, 268275.

Savage, M. L., and C. R. Stearns, 1985: Climate in the vicinity of Ross Island. Antarctica. Antarct. J. U.S., 20, 1-9.

Scott, R. F., 1907: The Voyage of the "Discovery." Vol. 1, C. Scribner's Sons, 410 pp.

Seefeldt, M. W., G. J. Tripoli, and C. R. Stearns, 2003: A highresolution numerical simulation of the wind flow in the Ross Island region, Antarctica. Mon. Wea. Rev., 131, 435-458.

Simmonds, I., K. Keay, and E.-P. Lim, 2003: Synoptic activity in the seas around Antarctica. Mon. Wea. Rev., 131, 272-288.

Simpson, G. G., 1919: Meteorology. Vol. 1, British Antarctic Expedition 1910-1913, Thacker, Spink and Co., 326 pp.

Sinclair, M. R., 1982: Weather observations in the Ross Island area, Antarctica. New Zealand Meteorological Service Tech. Note 253, 36 pp.

Slotten, H. R., and C. R. Stearns, 1987: Observations of the dynamics and kinematics of the atmospheric surface layer on the Ross Ice Shelf, Antarctica. J. Climate Appl. Meteor., 26, 1731-1743.

Stearns, C. R., 1997: Ross Island area wind field. Antarct. J. U.S., 33, 181-182.

— , and G. A. Weidner, 1993: Snow temperature, wind speed, and wind direction around the Pegasus Runway during 1992. Antarct. J. U.S., 28, 291-294.

- L. M. Keller, G. A. Weidner, and M. Sievers, 1993: Monthly mean climatic data for Antarctic automatic weather stations. Antarctic Meteorology and Climatology: Studies Based on Antarctic Automatic Weather Stations, D. H. Bromwich and C. R. Stearns, Eds., Antarctic Research Series, Vol. 61, Amer. Geophys. Union, 1-22.

Stull, R. B., 1988: An Introduction to Boundary Layer Meteorology. Kluwer Academic, 666 pp.

Thompson, D. C., 1968: Eleven years of temperature records at Scott Base. Antarctic, 5, 76-77.

- 1969: The coreless winter at Scott Base, Antarctica. Quart. J. Roy. Meteor. Soc., 95, 404-407.

- and W. J. P. McDonald, 1961: Meteorology, Scott Base. N. Z. Dep. Sci. Industr. Res. Bull., 140, 37-55.

, and - 1962: Radiation measurements at Scott Base. $N$. Z. J. Geol. Geophys., 5, 874-909.

van Loon, H., 1967: The half-yearly oscillations in the middle and high southern latitudes and the coreless winter. J. Atmos. Sci., 24, 472-486.

Zwally, H. J., J. C. Comiso, and A. L. Gordon, 1985: Antarctic offshore leads and polynyas and oceanographic effects. Oceanology of the Antarctic Continental Shelf, S. S. Jacobs, Ed., Antarctic Research Series, Vol. 43, Amer. Geophys. Union, 203-226. 